\title{
Carbon Cycle Learning of Chemistry Students: Modeling Method
}

\author{
Serpil Ozkurt Sivrikaya ${ }^{1}$ \\ ${ }^{1}$ Kocaeli University, Turkey \\ Correspondence: Serpil Ozkurt Sivrikaya, Kocaeli University, Turkey. E-mail: s_sivrikaya@yahoo.com
}

Received: April 20, 2020

Accepted: June 7, $2020 \quad$ Online Published: June 22, 2020

doi:10.5539/jel.v9n4p80

URL: https://doi.org/10.5539/jel.v9n4p80

\begin{abstract}
Science education tries to develop students thinking, linking, analyzing by embodying an abstract concept. The modeling method is used as one of the methods used in science education. This research in 2018-2019 academic year at Kocaeli Vocational School, was applied to students who are taking the course. In this survey, the qualitative method is preferred. The sample which consists of 22 people research and control groups involves 44 students. In the research, the pre-interview-final interview method was used for experimental and control groups. In the study; all the students were asked about the subject before the topic was told. Then the subject was explained to the experimental group by modeling method. The control group was told only verbally. Qualitative research was performed and data and significance analysis were used. As a result of this research, the carbon cycle, which plays an important role in the survival of the world, should be taught to students using materials that significantly affect learning.
\end{abstract}

Keywords: carbon cycle, modeling, qualitative research

\section{Introduction}

\subsection{Carbon and Carbon Cycle}

Ecologically important carbon $(\mathrm{C})$, water $\left(\mathrm{H}_{2} \mathrm{O}\right)$, oxygen $\left(\mathrm{O}_{2}\right)$, nitrogen $(\mathrm{N})$, sulfur $(\mathrm{S})$, phosphorus $(\mathrm{P})$ their ecosystem is interacting constantly substances with living organisms. Organisms take these substances they need to continue their vital activities and then give them back to their ecosystem. This circulation of substances in the ecosystem is called substance cycles.

These substances, which are necessary for life, are constantly reused by living things through loops. According to thermodynamic, the law is no substance that can be created or vice versa but through the physical and chemical processes, one can inverted to the others. So this cycle always happens if substances such as water, oxygen, carbon, phosphorus had not been transformed in the cycle in the continuation of life, these substances should have been destroyed until now. The fact that these substances, which are necessary for sustaining life, take place in the cyclic cycle makes it possible to repeat them continuously. The cycle between living beings and water, soil, and air ensures the continuity of life.

One of the substances in the ecosystem is carbon. Carbon is one of the elements of energy flow and chemical substance cycle in the ecosystem (Cansaran \& Yildırım, 2017). The atomic number is 6, formula is C.

$90 \%$ of the compounds in nature contains carbon content. Maintaining of the vital life and fulfilling vital living functions is a feature of carbon to combine with the other elements (www.kimyadersi.org). In nature, carbon can be found organically living being, graphite, coal, petroleum, tissue limestone, bicarbonate, and carbon dioxide.

The inorganic substances taken from the inanimate environment are transferred to living organisms and returned to the inanimate environment. It is said the substance cycle. Carbon, one of the inorganic elements, has this cycle, too. Carbon presents in the atmosphere as carbon dioxide. Ground and underground water contain carbon as $\mathrm{HCO}_{3}^{-}$or $\mathrm{CO}_{2}$ as a molecule. For this reason, carbon involves the basics of vital molecules.

There is carbon in the structures of organic molecules like the DNA that makes the living for this reason carbon is the basic structure of living things. It is stored in the atmosphere, hydrosphere and living things on the earth.

$\mathrm{H}_{2} \mathrm{O}$ and $\mathrm{CO}_{2}$ are not found side many stars (Gurbuz, 2008, p. 182). $\mathrm{CO}_{2}$ by carbon is often found in nature; the carbon $(\mathrm{C})$ and oxygen $(\mathrm{O})$ cycles are in interaction with each other. Carbon dioxide transferred to the atmosphere by breathing of living things and various combustion events are inverted to oxygen by photo 
synthesis of plants (Yıldız et al., 2005). $\mathrm{H}_{2} \mathrm{O}$ forms after oxygen combining with hydrogen (Turgutlu, 1999, p. 22). It is taken from plants by the food chain and transferred to humans and animals. With the burning of living things, part of the carbon in their bodies is transferred back to the atmosphere with the death of living things, the carbon remaining in the organism returns to the atmosphere with the help of bacteria or the consumption of fossil fuels, this cycle continues in this way (Ercan, 2009, p. 18). Besides this, eruption of magma by the volcanic movements causes the invasion of carbon to the atmosphere. The benefits of carbon are:

- It is the building stone of living organisms

- It is a source of renewable energy.

- It is a protector that adjusts the temperature of the World.

Besides the benefits of carbon, there are also damages. Its carbon moves together balanced with the oxygen cycle, there will be an environment that deteriorates living organisms by increasing carbon proportion in the atmosphere. Carbon dioxide and the other greenhouse gases change the balance in the gases in atmosphere and cause global warming (Ates \& Kartepe, 2013, p. 222).

After the leading greenhouse gas of carbon is followed by nitrogen oxide, methane, water vapor, chlorofluorocarbon. But carbon dioxide $\left(\mathrm{CO}_{2}\right)$ has a proportion of $82 \%$ with in all gases (Özcag, 2011; Dam, 2018, p. 164).

In order to sustain the vital assets of living thigs, a number of measures have been taken to reduce carbon emission. The Kyoto protocol comes at he beginning of these measures. The Kyoto Protocol is the only international agreement by fighting global warming and climate changes.

\subsection{Learning with Modeling Method}

Science teaching aims thinking, conceptualizing in the minds of learners' knowledge, establishing connections between reasons and results (Gülcicek \& Günes, 2004, p. 36).

Models that facilitate scientific thinking especially for abstract concepts are "structural, functional, causal" models (Unal Çoban \& Engin, 2013, p. 506).

Modeling, the formation of things, behavior, development process (Is1k \& Mercan, 2015, p. 1836) and product of this processing is called model (Düskün \& Unal, 2015, pp. 4-5; Bilen \& Ciltas, 2015, p. 41).

\section{Method}

The qualitative method has been adopted in the research applied to the students who took Environmental Chemistry course in 2018-2019 academic year in Kocaeli Vocational School Chemistry program. This research was carried out by the researcher herself. The experimental and control groups consisted of 22 students differently, 44 in total. Students answered the questions for 50 minutes during the lesson.

Students included in the experimental and control groups were randomly selected. Content analysis was performed on the obtained date. Content analysis is one of the qualitative research techniques. The question of "What is the effectiveness of modeling method in education?" constitutes the research problem.

In the research, experimental and control groups were determined by using pre-interview, interview methods. The experimental and control groups were made preliminary talks at the same time. During the pre-interview, students were asked "what is the carbon cycle?", "what are the benefits and damages?" these open-ended questions. The subject was told to experimental group by modeling method and verbal explanations were given.

At the last meeting, students were asked open-ended question that was asked pre-interview time. Teaching carbon cycle to students by using materials effects of learning searched in this research. In this research, data were obtained by pre-interview, interview methods in qualitative research. The effect of the modeling method on learning was measured.

\section{Results}

The main aim of the training is to gain behavioral change. Whether this change is desired level or not can be determined by interviews with experts (Basol, 2008). The effect of training with modeling methods on the behavioral changes and the effect on the learning level was measured by qualitative analysis techniques.

In an experimental study, the researcher examines the effect of the independent variable on the dependent variable. Therefore, the control group is used to determine the effect of the independent variable (Altunisik et al., 2012, p. 67).

Random sampling is in electing individuals from the total group to research or control groups in equally. Groups 
are effected by the independent variable is called the experiment group. Groups which have the same character with the experimental group but not exposed to the experiment is the called control group.

Open-ended questions can be asked semi-form or non-form interview. Such questions allow participants to express their thoughts in their own words (Altunısık et al., 2012, p. 87). Before the modelling method applied, students were asked open-ended questions like "what is the carbon cycle? what are the benefits and harms of carbon?" and wanted them to reply in a written way. Experiment group pre-interview (EP), experiment group last interview (EL) control group pre-interview (CP), control group last interview (CL) are named like these.

Table 1. Pre-interview and final-last interview test-control group statements

Expressions
EP1. "Carbon cycle will damage the environment and nature.
Therefore, the environment is polluted, living things are
damaged, so it is very harmful. Smoke, factories, exhaust fumes
are carbon sources."
EP2. "Carbon turns into oxygen by absorbing by plants."

EP3. "Carbon dioxide gas consists of carbon and oxygen"

EP4. "Fossil fuels, coal, graphite, contain carbon. It combines with oxygen and makes carbon dioxide."

EP5. " $\mathrm{CO}_{2}$ taken from atmosphere by plants is converted to nutrients by photosynthesis."

EP6. "Carbon atoms are the tissues forming substances. It is found in four ways in nature. Herbivorous animals meet carbon from plants. Carnivorous animals meet carbon by eating herbivorous animals."

EP7. "Carbon is present in nature. It helps the plants making photosynthesis. It is a hazardous gas. As a precaution chimney filters are taken. There are national agreements."

EP8. "Plants convert $\mathrm{CO}_{2}$ from atmosphere to nutrients. Thus, we take carbon from foods."

EP9. "Fossil fuels forms thanks to decomposers. Plants forms foods contains rich carbon by photosynthesis."

EP10. "Carbon forms oxygen and carbon dioxide. Plants should be planted."

CP1. "It is found four shapes in nature. It is the substance that forms the living tissues. The carbon cycle is completed by photosynthesis."

$\mathrm{CP} 2$. "Oxygen and carbon cycle are related to each other. $\mathrm{CO}_{2}$ is converted to oxygen by plants. Thus, oxygen and carbon cycle is formed. Humans, cars and factory gases produce carbon."

CP3. "Plants converts $\mathrm{CO}_{2}$ taken from atmosphere to foods that have plenty of carbon. Plants give off the oxygen to atmosphere. Oxygen is used by animals and humans. Exhaust gases, factory gases effect forming $\mathrm{CO}_{2}$ badly."

\section{Expressions}

EL1. "After physical, geological, chemical process cycling in atmosphere, oceans, earth is called carbon cycling. Carbon is found lithosphere, atmosphere, hydrosphere, atmosphere"

EL2. "The source of carbon can be found in atmosphere, lithosphere, hydrosphere and living organisms. It is found in atmosphere as $\mathrm{CO}_{2}$. It's found in lithosphere as limestone and coal. The cycle was drawn." EL3. "Carbon cycle is that carbon from exhaust gases, living organisms and fossil fuels turn back to nature as carbon and oxygen through plants."

EL4. 'It's important, since there are in all living things. It's present in the atmosphere as carbon and carbon dioxide. The addition of carbon to this cycle takes place by photosynthesis. Carbon released into the atmosphere as a result of plants taking carbon and leaving some of them back to the atmosphere. Plants continue their development with the remaining carbon. Herbivorous animals feed with animals. In life, carbon is given to atmosphere by respiration and excretion". The cycle was drawn by student.

EL5. "Carbon dioxide given by fossil fuels, factory chimneys is taken by plants and they gives the oxygen to atmosphere. It is called a loop." EL6. "Carbon is one of important element that forms the structures of living thing in ecosystem. Carbon can be found in all organic compounds. In the earth, the most important stores are $\mathrm{CO}_{2}$ in atmosphere; $\mathrm{CO}_{2}$ and $\mathrm{HCO}_{3}$ in water coal, petroleum, limestone in lands.

EL7. "Manufacturing plants converted the $\mathrm{CO}_{2}$ in atmosphere to nutritious foods those contain much carbon. It is a source of food for consumers in the food chain. Thus, carbon and oxygen are taken by consumers. Consumers use oxygen to consume nutrients and finally $\mathrm{CO}_{2}$ is given to the atmosphere. $\mathrm{CO}_{2}$ in the atmosphere cause the greenhouse effect and that makes the earth hotter. The loop had been drawn." EL8. "Carbon is found air that we breathe, coal and petroleum. It works with the oxygen cycle. The loop had been drawn."

EL9. "After fossil fuels are used $\mathrm{CO}_{2}$ is emitted."

EL10. "Animals and humans take in $\mathrm{O}_{2}$ and takes of $\mathrm{CO}_{2}$. Plants take in $\mathrm{CO}_{2}$ and take of $\mathrm{O}$ and they use carbon foods and grow. If there is too much $\mathrm{CO}_{2}$ in the atmosphere plants can't deal with it and it causes greenhouse effect finally it causes global warming."

CL1. "Plants convert $\mathrm{CO}_{2}$ in nature to $\mathrm{O}_{2}$. People and animals are used to burn this oxygen. If the $\mathrm{CO}_{2}$ gas is not used in photosynthesis in nature, greenhouse gases occur."

CL2. "Cars, factories and fossil fuels releases off $\mathrm{CO}_{2}$. Producing plants convert $\mathrm{CO}_{2}$ in atmosphere to $\mathrm{O}_{2}$ by photosynthesis. They give $\mathrm{O}_{2}$ to atmosphere. Plants are a source of food for consumers in the food chain. Thus, through foods from the plants $\mathrm{C}$ and $\mathrm{CO}_{2}$ are taken by consumers. Consumers take away $\mathrm{C}$ as $\mathrm{CO}_{2}$ by respiration."

CL3. "Carbon can be found 4 different types in nature. It forms the tissues of living things. Carbon cycle is occurred by photosynthesis. It is converted to oxygen is used by living things and given off to atmosphere as carbon dioxide." 
CP4. "Carbon forms the compounds that are in the structures of living things. Smokes form factory chimneys, car exhausts cause emitting of carbon and the cycle is effected. Oxygen and carbon cycle work together by photosynthesis."

CP5. "Carbon atoms form tissues and structures. If there is no $\mathrm{C}$ and $\mathrm{O}_{2}$, there aren't any living activities. If cycle deforms, there is no life."

CP6. "Carbon presents in the atmosphere. It allows people to take photosynthesis. Without carbon and oxygen, there is no vital activity. If the cycle breaks down, life is gone."

CP7. "Carbon cycle allows living things to live. Carbon means vital activities."

CP8. "Carbon cycle is that a cycle that allows living things to live in their world by chemical and herbal outputs."

CP9. "Carbon and oxygen are needed by all living things. Plants forms oxygen by using carbon dioxide in photosynthesis."

CP10. "Carbon cycle is a repeating action in the atmosphere, rain and underground water by sublimation."
CL4. "Plants converts $\mathrm{CO}_{2}$ taken form the atmosphere to foods that have plenty of carbon. In that time, oxygen is given off the atmosphere. After that $\mathrm{CO}_{2}$ is used by living things. Loop had been drawn."

CL5. "Plants convert $\mathrm{CO}_{2}$ taken from atmosphere to foods that have plenty of carbon. In this process, oxygen is given to the atmosphere."

CL6. "To make their own food, plants use sun shining to make photosynthesis and in this way they are grown. They form the food chain by taking $\mathrm{CO}_{2}$. If we plant trees, we reduce the quantity of $\mathrm{CO}_{2}$. Exhaust gases, fossil fuels, factory gases increase the formation of $\mathrm{CO}_{2}$ in atmosphere. Dead things, wastes, are recycled by decomposers and cycle is completed."

CL7. "Car exhaust, waste of factories from $\mathrm{CO}_{2}$. We can decrease $\mathrm{CO}_{2}$ by planting. Humans give off $\mathrm{CO}_{2}$ by respiration. We should plant green trees."

CL8. "Carbon cycle is an important cycle that forms the compounds of living things. Carbon can be found $\mathrm{CO}_{2}$ and bicarbonate in atmosphere and water. Plants convert $\mathrm{CO}_{2}$ taken from atmosphere to foods that have plenty of carbon and they give of oxygen to atmosphere."

CL9. "Carbon atoms in the atmosphere are emitted by humans and living things, exhaust gases and factories. After that, they are emitted as oxygen by plants thanks to photosynthesis. Human and living things use this $\mathrm{O}_{2}$ and emit as $\mathrm{CO}_{2}$ into the atmosphere."

CL10. "Plants take $\mathrm{CO}_{2}$ in the air and make it food by photosynthesis. At this time, they give the $\mathrm{O}_{2}$ to the atmosphere. This oxygen is used by humans and animals. Exhaust gases, unburned fossil fuels and factory gases affect $\mathrm{CO}_{2}$ formation in a bad way."

The total number of answers given by the students in the preliminary interview of the experimental group explains the carbon cycle. However, there are misconceptions about the carbon cycle about it gives damages to nature and the environment. 7 students associate the carbon cycle with the oxygen cycle. One student stated that he has four kinds of carbon sources but did not mention what these sources are. Another student (5) states that fossil fuels, coal, and diamond contain carbon, while (6) carbon forms living tissues. In the last meeting after the carbon cycle is explained to the experimental group by modeling method; it is seen that all students match the carbon cycle with the oxygen cycle students (1), (2), (6), (8) provided information about what carbon sources are Also, it was understood by students that carbon is necessary for life instead of conceptual mistakes about harmfulness of carbon. Instead, it was stated that excess carbon created a greenhouse effect and caused problems for living. Four students have drawn the carbon cycle on the answer sheets after the experiment.

Experiment group pre-interview and last-interview explanations are listed in the Table 2

Table 2. Pre-interview experimental group (EP)-Last interview experimental group (CP)

\begin{tabular}{lll}
\hline Pre- Interview & $\mathrm{N}$ & $\mathrm{f}$ \\
\hline Misconceptions about the carbon cycle about it gives damages to nature & 7 & $70 \%$ \\
Carbon is found in four forms in nature & 1 & $10 \%$ \\
Match the carbon cycle with the oxygen cycle & 7 & $70 \%$ \\
Last-Interview & & \\
Match the carbon cycle with the oxygen cycle & 10 & $100 \%$ \\
Carbon is found in four forms in nature & 4 & $40 \%$ \\
Drawn carbon cycle & 4 & $40 \%$ \\
\hline
\end{tabular}

Control group pre-interview and last-interview explanations are listed in the Table 3. 
Table 3. Experiment group last-interview (EL)-Control group last-interview (CL)

\begin{tabular}{lll}
\hline Pre-Interview & $\mathrm{N}$ & $\mathrm{F}$ \\
\hline Expression carbon cycle & 6 & $60 \%$ \\
The source of carbon & 2 & $20 \%$ \\
Expression simply carbon cycle (CP) & 4 & $40 \%$ \\
Last-Interview & & \\
Carbon cycle & 9 & $90 \%$ \\
Greenhouse gas & 1 & $10 \%$ \\
Drawn carbon cycle & 4 & $40 \%$ \\
\hline
\end{tabular}

In the preliminary interview of the control group students (1), (2), (3), (4), (6), (9) match the carbon cycle with the oxygen cycle (1) and (5) reported that carbon is present in four forms in nature and is only present in the living tissues of carbon as a source and did not provide information about other carbon sources. Also, students (4) stated that carbon was found in living tissues. Four students simply explained the carbon cycle. In the last interview after the carbon cycle was explained to the control group theoretically; all students except students (7) explained the cycle by matching the carbon cycle with the oxygen cycle. (1) stated that excess carbon dioxide causes greenhouse gas. Student (3) stated that carbon is found in four ways in nature and one of them is living tissues. None of the other students stated exactly what the carbon resources in nature were, except the number (8). The student (8) clearly defined the carbon cycle and stated that carbon is present in nature in bicarbonate, water, atmosphere, and living structure. The student (7) stated that carbon, as a factory waste is a harmful gas and greening, should be done. Only student (4) has drawn the carbon cycle.

\section{Discussion}

In the research, in which the carbon cycle was transferred to the students as experimental and control groups, it was investigated whether the modeling method has an effect on the understanding of the concept. Pre-test results in the carbon cycle show that the students in both groups have inadequate knowledge.

In last the interview of the experimental group, it was seen that all students match the carbon cycle with the oxygen cycle. In the last interview of the control group, it was determined that all students except one student match the carbon cycle with the oxygen cycle.

In the last interview of the experimental group, it was seen that four students gave complete information about the sources of carbon in nature. In the last interview of the control group, only one student stated exactly what the sources of carbon were in nature, and none of the students stated that living tissues were the source of carbon.

In the preliminary interview of the experimental group misconception and misinformation that carbon is harmful to the carbon cycle has been identified. However, in the last interview of the experimental group, it was seen that the carbon was necessary for life. It was pointed out that the greenhouse effect caused by excess carbon is harmful. In the last interview of the control group, while any one student was drawing a carbon cycle; in the last interview of the experimental group, four students drew the carbon cycle.

It was determined that the students considered exhaust, factory smoke as the cause of carbon emission in both preliminary interviews and last meeting. However, various combustion events, such as forest fires and volcanic events in nature are the events of the carbon cycle. Students participating Ural et al. (2017, p. 7) research answered the carbon source in the atmosphere as factory, exhaust gas, human and animals.

In Dogan et al. (2016, pp. 20-21) research, many students determined as the carbon cycle. Research on high school students, students emphasize the relationship between global fuels and global warming.

Arslan and Dogru (2014, p. 14) found that modeling did not affect students' level of understanding. Unal Çoban and Ergin's (2013, p. 515) research result shows that teaching with the method of modeling improves scientific knowledge and affects learning positively. Baskan Takaoglu (2015) found that students were developing their skills in modeling methods related to daily life.

As a result, the modeling method develops students' visual memories and makes the information meaningful. It is also possible to state that it is more permanent than the verbal expression method. Modeling methods can be used to describe other cycles of material. Besides this, there is a relationship between modeling method students' easy learning. In fact, it is examined in terms of there dimensions such as isomerism and complexity that students think about the subject. 


\section{Acknowledgments}

This article is an expanded version of the paper presented at the International Marmara Science and Social Sciences Congress held in 26-28 April 2019 in Kartepe/Kocaeli.

\section{References}

Altunışık, R., Coşkun, R., Bayraktaroğlu, S., \& Yıldırım, E. (2012). Sosyal bilimlerde araştırma yöntemleri SPSS uygulamall. Sakarya: Sakarya Yayıncilık.

Arslan, A., \& Doğru, M. (2014). Modellemeye dayalı fen öğretiminin ilköğretim öğrencilerinin anlama, hatırda tutma, yaratıcılık düzeyleri ile zihinsel modelleri üzerine etkisi. Mediterranean Journal of Humanities, 4(2), 1-17. https://doi.org/10.13114/MJH.201428425

Ateş, M., \& Karatepe, A. (2013). Üniversite öğrencilerinin "küresel 1sınma" kavramına ilişkin algılarının metaforlar yardımıla analizi. Marmara Coğrafya Dergisi, 27, 221-241.

Başkan, T. Z. (2015). Matematiksel modelleme kullanılan fizik derslerinin öğretmen adaylarının ilgi, günlük hayat ve diğer derslerle ilişkilendirmelerine etkisi. YYÜ Eğitim Fakültesi Dergisi, 12(1), 223-263.

Başol, G. (2008). Bilimsel araştırma süreci ve yöntem. Retrieved January 2, 2019, from https://www.researchgate.net/profile/Guelsah_Basol2/publication/292391179_Bilimsel_arastirma_sureci_ve _yontem/links/56ae14a308ae43a3980e6828.pdf

Bilen, N., \& Çiltaş, A. (2015). Ortaokul matematik dersi beşinci sınıf öğretim programı'nın öğretmen görüşlerine göre matematiksel model ve modelleme açısından incelemesi. Kafkas Ĕ̈itim Araşstırmaları Dergisi, 2(2), $40-54$.

Cansaran, A., \& Yıldırım, C. (2014). Çevre eğitimi. In O. Bozkurt (Ed.), Çevre bilimi ile ilgili başlıca terimler ve kavramlar (pp. 1-17). Pegem Yayınları: Ankara. https://doi.org/10.14527/9786055885205.01

Dam, M. M. (2018). Enerji ve büyümenin çevre kirliliğine etkisi: AB ülkeleri için panel veri analizi. Adnan Menderes Üniversitesi Sosyal Bilimler Enstitüsü Dergisi, 5(2), 163-174. https://doi.org/10.30803/adusobed.423303

Doğan, Ö. K., Kutay, Y., \& Çakır, M. (2016). Lise öğrencilerinin güncel çevre sorunları hakkındaki algıları: İzmir örneği. Marmara Üniversitesi Atatürk Eğitim Fakültesi Eğitim Bilimleri Dergisi, 44, 15-31. https://doi.org/10.15285/maruaebd.286483

Düşkün, İ., \& Ünal, İ. (2015). Modelle Öğretim Yönteminin Fen Eğitimindeki Yeri ve Önemi. Mehmet Akif Ersoy Üniversitesi Eğitim Bilimleri Dergisi, 4(6), 1-18.

Ercan, S. (2009). Yapılandırmacı öğrenme yaklaşımı 5e öğretim modelinin madde döngüleri konusunun ögretilmesine etkisi. Gazi Üniversitesi Eğitim Bilimleri Enstitüsü Basılmamış Yüksek Lisans Tezi, Ankara.

Gülçiçek, Ç., \& Güneş, B. (2004). Fen öğretiminde kavramların somutlaştırılması: modelleme stratejisi, bilgisayar simülasyonları ve analojiler. Eğitim ve Bilim, 29(134), 36-48.

Gündüz, T. (2008). Çevre kimyası. Ankara: Gazi kitapevi.

Işık, A., \& Mercan, E. (2015). Ortaokul matematik öğretmenlerinin model ve modelleme hakkındaki görüşlerinin incelenmesi. K. Ü. Kastamonu Eğitim Dergisi, 23(4), 1835-1850.

Karbon. (2018). Retrieved January 2, 2019, from https://www.kimyadersi.org/karbon.html

Tarakçı, F. (1999). Çevre ve insan. İstanbul: Önde Yayıncılık.

Ünal, Ç. G., \& Ergin, Ö. (2013). Modellemeye dayalı fen öğretiminin etkilerinin bilimsel bilgi açısından incelenmesi. Hacettepe Üniversitesi Ĕ̆itim Fakültesi Dergisi, 28(2), 505-520.

Ural, E., Ercan, O., \& Bilen, K. (2017). Pre-service science teachers' misconceptions of carbon cycle and global warming. Bilimsel Eğitim Araştırmalarl, 1(1), 1-17.

Yıldız, K., Sipahioğlu, Ş., \& Yılmaz, M. (2005). Çevre bilimi. Ankara: Gündüz Eğitim ve Yayıncılık.

\section{Copyrights}

Copyright for this article is retained by the author, with first publication rights granted to the journal.

This is an open-access article distributed under the terms and conditions of the Creative Commons Attribution license (http://creativecommons.org/licenses/by/4.0/). 